\title{
Short communication: A pilot study to describe duodenal and ileal flows of nutrients and to estimate small intestine endogenous protein losses in weaned calves
}

\author{
I. Ansia, ${ }^{1}$ (1) H. H. Stein, ${ }^{1}$ C. Brøkner, ${ }^{2}$ and J. K. Drackley ${ }^{1 *}{ }^{1}$ () \\ ${ }^{1}$ Department of Animal Sciences, University of Illinois, Urbana 61801 \\ ${ }^{2}$ Hamlet Protein A/S, Horsens, Denmark 8700
}

\begin{abstract}
The aims of this pilot study were (1) to evaluate the effect of an ileal and duodenal cannulation surgery on body weight and dry matter intake, (2) to estimate endogenous losses of crude protein $(\mathrm{CP})$ and $\mathrm{AA}$ in the small intestine, and (3) to describe duodenal and ileal flows of nutrients in weaned dairy calves. Three Holstein male calves were fitted at 7 wk of life with a T-cannula at the terminal ileum and another cannula at the proximal duodenum. On wk 14 of life, calves were randomly assigned to a single $3 \times 3$ Latin square with $10-d$ periods. The 3 diets were fed ad libitum and consisted of a control calf starter (CS) with conventional soybean meal (SBM) as the main source of protein (CTRL), an isonitrogenous $(20 \% \mathrm{CP}) \mathrm{CS}$ with an enzyme-treated SBM as the main source of protein (ENZT), and a CS with low content of CP (10\%) and no soy protein (LOCP). Flows and digestibilities of nutrients were compared between the soy-based highprotein diets (HICP) and LOCP, and between CTRL and ENZT. Final data were only available from 2 calves per diet $(\mathrm{n}=2)$ because cannulas from 1 calf became inoperative after the first collection period. Duodenal flows of $\mathrm{CP}$, total AA, nonprotein nitrogen, microbial $\mathrm{N}$, and fatty acids, as well as apparent duodenal digestibility of starch, were greater for HICP than for LOCP, indicating a greater foregut microbial activity and digestion. The apparent ileal digestibility (AID) of organic matter, $\mathrm{CP}$, and total AA were greater for HICP than for LOCP. Duodenal net flow of CP was greater for ENZT than for CTRL, but flow of AA was not different. On the other hand, duodenal flow of microbial $\mathrm{N}$ was greater, and flows of nonprotein $\mathrm{N}$ and starch were lower for the ENZT diet, suggesting a more efficient microbial activity in the rumen. Even though CTRL had a greater AID when compared with ENZT,
\end{abstract}

Received January 29, 2020.

Accepted May 28, 2020.

*Corresponding author: drackley@illinois.edu the AID of CP and AA were greater for enzyme-treated SBM than for SBM. Endogenous losses in the small intestine per kilogram of duodenal dry matter flow were $47 \pm 15$ and $37 \pm 12 \mathrm{~g} / \mathrm{d}$, and the true ileal digestibilities for the HICP diets were $86 \pm 0.1$ and $87 \pm 0.1 \%$ for $\mathrm{CP}$ and AA, respectively. An optimal supply of $\mathrm{CP}$ and the inclusion of an enzyme-treated SBM improved the efficiency of microbial digestion and increased AA absorption. Although further research with greater biological replication is needed, our results indicate that there is potential to improve digestion and absorption of proteins through dietary strategies in young weaned calves.

Key words: weaned calves, digestibility, endogenous protein, digesta flows

\section{Short Communication}

Digestibility of dietary nutrients is the most common method to estimate nutrient bioavailability, especially for dietary AA. Ileal digestibility is a more accurate estimation of AA and $\mathrm{N}$ bioavailability than total-tract digestibility because AA are only absorbed in the small intestine, and fermentation in the large intestine alters AA profile and $\mathrm{N}$ content in feces (Stein et al., 2007). In ruminants, microbial $\mathrm{N}$ accounts for most of the total duodenal N (Marini et al., 2008), and therefore duodenal $\mathrm{N}$ supply must be studied to accurately determine dietary $\mathrm{N}$ digestibilities. Moreover, $\mathrm{N}$ recycling in the rumen should also be considered because it is a key mechanism to supply $\mathrm{N}$ to the ruminal microorganisms when degradable protein is deficient or if there is an asynchrony of carbohydrate and N supply (Reynolds and Kristensen, 2008). To our knowledge, only a few experiments have determined the small intestine digestibility of solid feed and digestive tract function in young postweaned calves (Khorasani et al., 1990; Lallès and Poncet, 1990).

Antinutritional factors in soybeans impart a significant negative effect on the digestive tract function, and therefore on calf performance (Huisman and Jansman, 
1991). Modern value-added feed ingredients for calves such as microbially-treated or fermented soy protein not only reduce the activity of antinutritional factors in soy proteins, but also decrease peptide size and release bioactive components that promote gastrointestinal and overall health (Kim et al., 2010, 2012; Kwon et al., 2011; Chatterjee et al., 2018).

There is a need for more data about duodenal flows and ileal absorption of nutrients in young postweaned calves under modern feeding conditions. Our objectives were (1) to evaluate the effect of an ileal and duodenal cannulation surgery on BW and DMI using a brokenline model in weaned dairy calves, (2) to estimate endogenous losses of $\mathrm{CP}$ and $\mathrm{AA}$ in the small intestine, and (3) to describe duodenal and ileal flows of nutrients with different diets in weaned dairy calves.

The Institutional Animal Care and Use Committee at the University of Illinois at Urbana-Champaign approved all procedures described here (protocol \#18087). Three Holstein male calves were transported at approximately $19 \mathrm{~d}$ of age from the Dairy Cattle Research Unit to the Nutrition Field Laboratory at the University of Illinois. Calves were housed individually in outdoor polyvinyl chloride hutches placed on crushed limestone and bedded with straw. Twice daily (0630 and $1830 \mathrm{~h}$ ), calves were fed a commercial milk replacer (28.5\% CP, $15 \%$ fat; Excelerate, Milk Specialties Global Animal Nutrition, Eden Prairie, MN) reconstituted to $15 \%$ solids and fed at a rate of $2 \%$ (DM) of BW until wk 4 of life, $1.5 \%$ in wk 5 , and $1 \%$ in wk 6 and 7 . Milk replacer was gradually reduced over $1 \mathrm{wk}$ and calves were weaned at wk 8 of age. Calves had ad libitum access to water and to a commercial calf starter (CS; 22\% CP; AmpliCalf Grower, Purina Animal Nutrition LLC, Shoreview, MN). At wk 10, the CS was substituted with an experimental CS that was later used as the control diet. The CS was multitextured and offered in a bucket mixed with 5\% (as-fed basis) chopped grass hay until the end of the experiment.

At $7 \mathrm{wk}$ of life, calves were surgically fitted with a T-cannula in the terminal ileum and another T-cannula in the proximal duodenum during the same surgical procedure. Pre-surgery care and surgical procedures were as described by Ansia et al. (2019). The surgical methodology was similar for inserting both cannulas, with the exception that the duodenal cannula was inserted at the proximal duodenum 15 to $20 \mathrm{~cm}$ caudal to the pylorus (i.e., just caudal to the pancreatic and biliary ducts).

At wk 14 of life, calves were randomly assigned to a single $3 \times 3$ Latin square with 10 -d periods. The 3 diets (Table 1) were offered ad libitum and consisted of: a control CS with conventional soybean meal (SBM) as the main source of protein (CTRL), an isonitrogenous
Table 1. Ingredient and chemical composition of diets

\begin{tabular}{lccc}
\hline & \multicolumn{3}{c}{ Diet $^{1}$} \\
\cline { 2 - 4 } Item & CTRL & ENZT & LOCP \\
\hline Ingredient, \% & & & \\
Cracked corn & 22.50 & 22.50 & 22.50 \\
Whole oats & 16.50 & 16.50 & 16.50 \\
Molasses & 5.20 & 5.20 & 5.20 \\
Pellet & 55.85 & 55.85 & 55.80 \\
Beet pulp shreds & 9.28 & 20.08 & 45.04 \\
Wheat middlings & 12.13 & 13.99 & 37.54 \\
Soybean meal, 48\% CP & 51.54 & - & - \\
HP-RumenStart & & 39.90 & - \\
Ground corn & - & 17.33 & 8.80 \\
Vitamin-mineral premix & & & \\
Titanium dioxide & 18.44 & 7.97 & 7.98 \\
Chemical composition, g/kg of DM & 7.98 & 0.72 & 0.72 \\
CP & & & \\
Total AA & 199 & 206 & 104 \\
NPN & 181 & 177 & 86 \\
Starch & 1.72 & 1.73 & 2.07 \\
Fatty acids & 332 & 316 & 322 \\
NDF & 37.0 & 34.8 & 35.8 \\
Ash & 196 & 241 & 280 \\
Ca & 88.6 & 90.4 & 87.3 \\
P & 14.9 & 15.0 & 14.9 \\
& 5.71 & 5.49 & 5.49 \\
\hline
\end{tabular}

$\overline{{ }^{1} \text { Calves were fed ad libitum a control calf starter (CS) with convention- }}$ al soybean meal as the main source of protein (CTRL), an isonitrogenous CS with an enzyme-treated soybean meal as the main source of protein (ENZT), or a CS with low content of CP (LOCP).

${ }^{2}$ Enzyme-treated soybean meal (Hamlet Protein, Horsens, Denmark). ${ }^{3}$ Calcium carbonate: $5.4 \%$; monocalcium phosphate: $1.4 \%$; magnesium oxide: $0.12 \%$; sodium chloride: $0.7 \%$; trace mineral and vitamin mix: $0.3 \%$ (ADM Animal Nutrition, Decatur, IL). Twenty-six kIU of vitamin $\mathrm{A} / \mathrm{kg}$ of DM, $6 \mathrm{kIU}$ of vitamin D/kg of DM, $30 \mathrm{IU}$ of vitamin E/ $\mathrm{kg}$ of DM.

CS (20\% CP) with an enzyme-treated soybean meal (ESBM; HP-RumenStart, Hamlet Protein A/S, Horsens, Denmark) instead (ENZT), and a CS with $10 \%$ $\mathrm{CP}$ and no soy (LOCP) that was used as basal diet for estimating ingredient digestibility and endogenous losses. Titanium dioxide (0.4\% DM basis) and acid insoluble ash were used as indigestible markers.

On d 7 and 8 of each period, a 250-mL plastic bag (Nurser standard liners, Playtex, North Bergen, NJ) was attached to the cannula in the ileum with an autolocking cable tie after removing the cap of the cannula. Bags were continuously removed when full or approximately every $30 \mathrm{~min}$ from 0630 until $1830 \mathrm{~h}$. The same procedure was performed on d 9 and d 10 in the duodenum, with the exception that collection was restricted to intervals of $2 \mathrm{~h}$ with 2 -h periods of no collection in between to avoid excessive loss of nutrients and fluids. Starting time of duodenal collection alternated between days to cover the whole timeframe within a day. For each bag, digesta $\mathrm{pH}$ was measured immediately with a portable pH meter (Accumet AP110, Fisher Scientific, Atlanta, GA), and the content was frozen thereafter. Samples were pooled by calf and period. Calf starter 
samples were collected every second day starting on d 4 of each period, and composited by period before analysis. Dry matter and ash were determined for all CS and freeze-dried digesta by drying in a forced-air oven at $135^{\circ} \mathrm{C}$ for $2 \mathrm{~h}$ and $600^{\circ} \mathrm{C}$ for $3 \mathrm{~h}$, respectively. Complete AA profile, CP, acid insoluble ash, NDF, NPN, starch, fatty acids, minerals, and Ti concentrations were determined in feed and digesta samples at the Agricultural Experimental Station Laboratory of the University of Missouri-Columbia using official or validated methods.

As a marker of microbial N, total DNA was extracted from freeze-dried digesta using a QIAamp PowerFecal DNA kit (Catalog No. 12830-50; Qiagen, Hilden, Germany). Sample DNA concentration was quantified using a Nanodrop spectrophotometer (Nyxor Biotech, Paris, France). Crude mucin and microbial cells were extracted by digesta fractionation (Montoya et al., 2015). Freeze-dried digesta was first reconstituted (1:20, wt:vol at room temperature) in saline solution $(0.15$ $\mathrm{mol} / \mathrm{L}$ ) and centrifuged at $250 \times g$ for $15 \mathrm{~min}$ at $4^{\circ} \mathrm{C}$. Supernatant was then centrifuged at $14,500 \times g$ for 30 min at $4^{\circ} \mathrm{C}$. This second precipitate contained microbial cells and $\mathrm{CP}$, and DNA concentrations were measured on it to use the coefficient DNA/total $\mathrm{N}$ to estimate total microbial $\mathrm{N}$ per kilogram of digesta DM in duodenal samples. The supernatant contained soluble N components and was mixed with ethanol (1:1.5, vol: vol at $0^{\circ} \mathrm{C}$ ), kept overnight at $-20^{\circ} \mathrm{C}$, and centrifuged at $1,400 \times \mathrm{g}$ for $10 \mathrm{~min}$ at $4^{\circ} \mathrm{C}$. This precipitate constituted the total crude mucin and was recovered in $15 \mathrm{~mL}$ of saline solution and precipitated again with ethanol in the same conditions, recovered, freeze-dried, and weighed. Body weight was recorded weekly since arrival and then between experimental periods. Body weight averaged $95 \pm 13$ (SD) $\mathrm{kg}$ at the beginning of the experiment (wk 14). Water and DM intake were measured twice daily.

The flow of any nutrient expressed in grams per kilogram of DMI was calculated by multiplying their concentration $(\mathrm{g} / \mathrm{kg}$ of $\mathrm{DM})$ in digesta (duodenal or ileal) by the flow of DM at that location. Duodenal and ileal digesta DM flow was calculated by dividing the concentration of each marker ( $\mathrm{Ti}$ and acid insoluble ash) in diet or duodenal digesta ( $\mathrm{g} / \mathrm{kg}$ of DMI) by their concentration in duodenal or ileal digesta, respectively (Montagne et al., 2000). The DM flows obtained with each marker were averaged for each site. The apparent duodenal (ADD) and ileal (AID) digestibility of any given nutrient was estimated by the percentage disappearance between its concentration in the diet and its flow at the duodenum, and between its duodenal and ileal flow, respectively. The apparently true duodenal digestibilities (ATDD) of CP, AA, and OM were esti- mated by correcting the total duodenal $\mathrm{N}$ concentration by the concentration of microbial N. Digestibility of CP and $\mathrm{AA}$ in the test ingredients (SBM and $\mathrm{ESBM}$ ) was determined by the difference method using the LOCP diet as a basal diet (Kong and Adeola, 2014). The linear relationship between the $\mathrm{CP}$ or $\mathrm{AA}$ absorbed in the small intestine (digestible $\mathrm{CP}_{\text {ileo }}$ ) and the respective contents of duodenal flow $\left(\mathrm{CP}_{\text {duo }}\right)$ can be expressed according to the following equation:

$$
\text { Digestible } \mathrm{CP}_{\text {ileo }}=\mathrm{CP}_{\text {endo }}+a \times \mathrm{CP}_{\text {duo }} \text {, }
$$

where the intercept of the regression $\left(\mathrm{CP}_{\text {endo }}\right)$ is the flow of basal intestinal endogenous CP losses (flow of $\mathrm{CP}$ at zero duodenal CP flow), and the slope (a) is an estimate of the true digestibility of CP (Mariz et al., 2018). Endogenous proteins originate in the form of mucus, saliva, shredded cells, bile, digestive enzymes, and hair across the digestive tract. Endogenous proteins do not represent a large percentage $(\sim 13 \%)$ of the total $\mathrm{N}$ leaving the abomasum in adult cows, but account for approximately $60 \%$ of the total $\mathrm{N}$ reaching the end of the ileum (Ouellet et al., 2002; Marini et al., 2008). Therefore, endogenous protein losses should be considered to accurately estimate small intestinal digestibilities of dietary protein.

Digesta $\mathrm{pH}, \mathrm{ADG}, \mathrm{DM}$ and water intakes, $\mathrm{ADD}$, AID, and flow of nutrients among diets were analyzed as mixed-effect models with diet, period, day (only for intakes), and time (only for digesta $\mathrm{pH}$ ) as fixed effects, calf as a random effect, and DMI as a percentage of $\mathrm{BW}$ as a covariate within the PROC GLIMMIX procedure in SAS version 9.4 (Cary, NC). The CONTRAST statement was used to compare the 2 soy-based high-protein diets (HICP; $\mathrm{n}=4)$ with the LOCP $(\mathrm{n}=2)$ diet, and the CTRL with the ENZT diet. The covariance structure that resulted in the smallest Bayesian and Akaike information criteria was chosen for all analyses. A 1-sample $t$ - test was performed on the ADD and AID means for each treatment to determine if a net outflow or inflow exists (i.e., means by treatment different than zero) using the TTEST procedure in SAS with a $95 \%$ confidence interval. Assumptions about the normality and homogeneity of residuals derived from all the ANOVA were checked using the PROC UNIVARIATE procedure in SAS.

To evaluate the effect of surgery on growth and DMI, the mean weekly BW of the 3 calves from arrival (wk 3) until the beginning of the experiment (wk 14) were fitted to the best broken-line model as described previously (Ansia et al., 2019). The parameters of the selected model $\left\{\mathrm{BW}=a+\left[b_{1} \times \min \left(\mathrm{wk}-x_{1}\right)\right]+\left[b_{2}\right.\right.$ $\times \max \left(0\right.$, wk- $\left.\left.\left.x_{2}\right)\right]\right\}\left(P<0.001\right.$, adjusted $\left.\mathrm{R}^{2}=0.99\right)$ 
represented a plateau $(a)$ on BW gain of almost $2 \mathrm{wk}$ from $6.6 \mathrm{wk}\left(x_{1}\right)$ until $8.5 \mathrm{wk}\left(x_{2}\right)$, which corresponded with the time of the surgery (wk 7). The model identified different slopes of growth before $\left(b_{1}=6.5 \mathrm{~kg} / \mathrm{wk}\right)$ and after the plateau $\left(b_{2}=5.7 \mathrm{~kg} / \mathrm{wk}\right)$, which may point out a detrimental effect on growth due to surgery and body tissue adaptation to the cannulas, or due to reduced solid food intake. Milk replacer intake was not affected by surgery, but starter intake sstarter intake $\left.=a+\left[b_{1} \times \max \left(0, \mathrm{~d}-x_{1}\right)\right]-\left[b_{2} \times \max \left(0, \mathrm{~d}-x_{2}\right)\right]\right\}(P$ $<0.001$, adjusted $\left.\mathrm{R}^{2}=0.92\right)$ plateaued $(a)$ at $340 \mathrm{~g} / \mathrm{d}$ from the surgery until $7\left(x_{1}\right)$ days later. After that, starter intake increased at a pace of $237 \mathrm{~g} / \mathrm{d}\left(b_{1}\right)$ until d 18 postsurgery $\left(x_{2}\right)$ when the rate of increase slowed to $46 \mathrm{~g} / \mathrm{d}\left(b_{2}\right)$, which is closer to the slope observed before surgery $(33 \mathrm{~g} / \mathrm{d})$. The difference in growth slopes $(0.8$ $\mathrm{kg} /$ wk) agreed with the difference between calves with or without ileal cannulas $(0.86 \mathrm{~kg} / \mathrm{wk})$ found in our previous work with younger calves (Ansia et al., 2019).

Ileal and duodenal cannulas in 1 of the calves became inoperative after the first collection period from the ileum. Therefore, the duodenal flows and digestibility data are only from 2 calves per diet $(\mathrm{n}=2)$ and ileal flows are from all calves $(\mathrm{n}=3)$ during 1 period only. Due to the low sample size, comparisons must be considered cautiously; however, this data set can serve as an exploratory picture of the digestive metabolism in young weaned calves. Despite lower $(P<0.01)$ starter and water intakes for ENZT than CTRL (Table 2), we found no differences in ADG between diets. Two of the diet characteristics, ad libitum intake and the multitextured form of the starter, were chosen to promote the greatest DMI possible and ensure an optimal calf growth and digestive health. A different approach, such as pair-feeding and use of a pelleted diet, could have been interesting to eliminate the possible consequences of the DMI variability on digestion.

Flow of OM per kilogram of DMI at the duodenum was lower $(P<0.001)$ with LOCP than HICP. Flows of NPN and net flows of CP and total AA were greater $(P<0.01)$ with HICP than LOCP (Table 2). Microbial $\mathrm{N}$ flow, microbial efficiency, and the proportion of microbial $\mathrm{N}$ relative to total duodenal $\mathrm{N}$ were greater $(P$ $<0.001)$ with HICP than LOCP. Flows of starch, fatty acids, and NDF were lower $(P<0.001)$ with HICP than LOCP. The ATDD of CP, total AA, and ADD of starch were greater $(P<0.001)$ with HICP than LOCP (Table 3). The duodenal flows of OM, starch, ash, and the net flow of $\mathrm{CP}$ were lower $(P<0.01)$ with ENZT than CTRL. However, duodenal net flows of total AA tended $(P=0.06)$ to be greater with ENZT than CTRL. Duodenal flows of NPN were lower $(P<0.001)$, but those of microbial $\mathrm{N}(P<0.001)$ were greater with ENZT in comparison with CTRL. Efficiency of micro- bial protein synthesis and the proportion of microbial to total $\mathrm{N}$ were greater $(P<0.001)$ with ENZT than with CTRL. Comparing only the test ingredients, we observed a greater ATDD of $\mathrm{CP}(P<0.001)$ and total AA $(P<0.01)$ with ESBM than with SBM.

Ileal flows with LOCP of OM $(P=0.01)$, starch $(P$ $<0.001)$, and NDF $(P<0.001)$ were greater, and those of fatty acids $(P=0.04), \mathrm{CP}(P<0.001)$, total AA $(P$ $<0.001)$ and NPN $(P<0.001)$ were lower than with HICP (Table 2). The ENZT diet resulted in greater $(P$ $<0.001$ ) flows of fatty acids, ash, CP, total AA, and NPN than CTRL at the ileum. However, ileal flows of OM $(P<0.001)$, starch $(P<0.01)$, and NDF $(P$ $<0.001)$ were lower with ENZT than CTRL. Mucin protein flow at the ileum was greater $(P=0.02)$ for HICP than for LOCP, and greater $(P<0.001)$ with ENZT than with CTRL.

Despite the small biological replication of this pilot experiment, differences in foregut digestion and intestinal digestibility were observed between diets with different $\mathrm{CP}$ contents. We found a reduced duodenal outflow of microbial N and NPN with the LOCP diet that indicated a decreased ruminal microbial fermentation, and likely a reduced postruminal digestion (Klusmeyer et al., 1990; Meissner and Du Preez, 2009), which may have been a result of the lack of degradable protein entering the rumen (Reynal and Broderick, 2003). In addition, the lower duodenal outflow of fatty acids is indicative of reduced microbial activity because microbial synthesis of fatty acids (mainly odd- and branched-chain fatty acids) in the rumen can substantially contribute to the total duodenal fatty acids outflow (Prado et al., 2019). This reduced microbial activity also may result in a decline in starch utilization by microbes as reflected by the lower ADD of starch with the LOCP diet (Khan et al., 2008; Seo et al., 2013). A diet between 11 and $12 \% \mathrm{CP}(\mathrm{DM})$ is required to maintain the minimum ammonia concentration in the rumen to maximize microbial protein synthesis efficiency (Klusmeyer et al., 1990; Clark et al., 1992). The LOCP diet of $10 \%$ CP probably did not supply a constant level of ruminal ammonia and may have diminished microbial efficiency when compared with a $20 \%$ CP diet (Valkeners et al., 2004). In addition, microbial uptake of recycled urea-N is limited (Marini et al., 2008; Reynolds and Kristensen, 2008), and microbial growth using it is not as efficient as with peptide-N or AA-N (Bach et al., 2005).

The inefficient rumen fermentation and postruminal digestion may have contributed to the lower AID of CP $(P<0.01)$ and AA $(P<0.01)$ observed with LOCP compared with the soy-based high-protein diets (Hvelplund and Hesselholt, 1987; van Bruchem et al., 1989). Even though a decrease in NDF ruminal disappearance was expected with the LOCP diet, we observed no in- 
fluence of dietary $\mathrm{CP}$ level and, overall, values across the 3 diets were close to those reported in adult cows (Ipharraguerre et al., 2002). Negative NDF digestibility in the small intestine is also found in adult cattle (Panah et al., 2020) and has been attributed to a deficient representation of the particle flow by the markers (Olijhoek et al., 2016). Moreover, other components of the ileal digesta such as glycoproteins, microbes, and sloughed epithelial cells share some of the same sugar residues as dietary fiber and are analyzed as dietary fiber using the NDF method (Montoya et al., 2016). In our study, the greater mucin content in LOCP may have contributed to the larger NDF pool compared with the HICP diets. Also, the small sample size of this experiment may have limited our ability to accurately determine AID of nutrients that are in a low concentration in ileal digesta due to a relatively high ADD, such as $\mathrm{OM}, \mathrm{NDF}$, or starch.

Enzymatic treatment of feed ingredients can promote microbial protein synthesis by increasing its ruminal degradability, even without modifying its chemical composition (Seo et al., 2013). The greater duodenal flow of microbial $\mathrm{N}$ with ENZT was accompanied by a greater ADD of starch and a reduction in NPN flow in comparison with CTRL, indicating a greater microbial efficiency of carbohydrate digestion and ammonia in-

Table 2. Least squares means for ADG, DM and water intake, digesta pH, and digesta flows of nutrients at the duodenum and ileum of 3-moold weaned calves

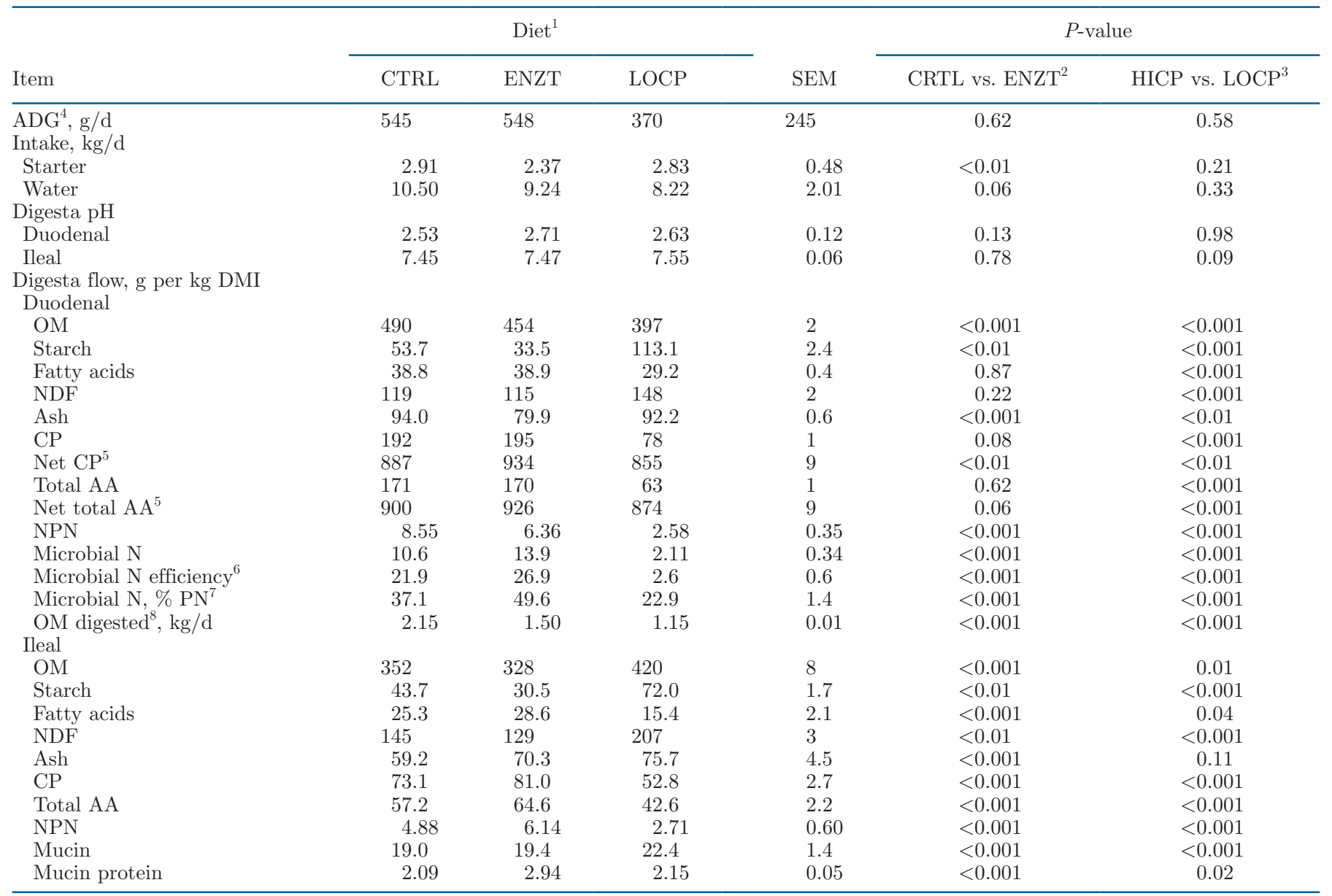

${ }^{1}$ Calves were fed ad libitum a control calf starter (CS) with conventional soybean meal as the main source of protein (CTRL), an isonitrogenous CS with an enzyme-treated soybean meal as the main source of protein (ENZT), or a CS with low content of CP (LOCP).

${ }^{2} P$-value of the orthogonal contrast between CTRL and ENZT diets.

${ }^{3} P$-value of the orthogonal contrast of CTRL and ENZT (HICP) against LOCP.

${ }^{4} \mathrm{ADG}$ of each $10-\mathrm{d}$ period.

${ }^{5}$ Duodenal flow of a nutrient relative to the dietary intake of that specific nutrient.

${ }^{6}$ Grams of microbial N per kilogram of OM truly digested before reaching the duodenum.

${ }^{7}$ Grams of microbial $\mathrm{N}$ as a percentage of the total duodenal flow of protein $\mathrm{N}$.

${ }^{8}$ Amount in kilograms per day of OM disappeared before reaching the duodenum. 
corporation into microbial protein (Hoover and Stokes, 1991; Seo et al., 2013). Enzymatic hydrolysis of soy protein increases the proportion of small sized molecules and reduces the presence of antinutritional factors, which promotes ruminal microbial activity (Reynal and Broderick, 2003; D'Mello, 2006) and may improve small intestinal digestion (Feng et al., 2007). Even though AID for $\mathrm{CP}(P<0.01)$ and AA $(P<0.01)$ was reduced for ENZT diet compared with CTRL, the AID of the ESBM itself was greater relative to SBM for both $\mathrm{CP}$ and $\mathrm{AA}$. It needs to be noted that the difference method assumes an equal digestibility of the basal diet ingredients in diets with different $\mathrm{CP}$ content, which may be true for nonruminants, but it can have an effect in ruminants due to the different profile of nutrients available for microbial fermentation as we observed in this study. Nevertheless, it could still be a valid method of comparison for diets differing only in the protein source because the same basal diet digestibility is used to determine ingredient digestibility values in the other diets. However, this is only an estimation approach and other methods (e.g., duodenal infusions, isotope labeling) may be more appropriate to measure small intestinal digestibilities of feed ingredients.

Basal endogenous losses in the small intestine per kilogram of duodenal DM flow were $47 \pm 15$ and $37 \pm$ $12 \mathrm{~g}$ of $\mathrm{CP}$ (adjusted $\mathrm{R}^{2}=0.90, P<0.001$, root mean square error $=16.26)$ and AA (adjusted $\mathrm{R}^{2}=0.90, P$ $<0.001$, root mean square error $=13.77)$, respectively. These losses (5.60 g $\pm 2.72 \mathrm{~N} / \mathrm{kg}$ of duodenal OM) coincide with those in adult dairy cows $(5.60 \pm 0.53 \mathrm{~g}$ $\mathrm{N} / \mathrm{kg}$ of duodenal $\mathrm{OM}$ ) as reviewed by Marini et al., (2008) and represent $61 \%$ of the total flow of CP and AA at the ileum. Assuming that true digestibility of $\mathrm{N}$ is not different between ENZT and CTRL diets, the true ileal digestibility was $86 \pm 8.6 \%$ and $87 \pm 8.6 \%$ for $\mathrm{CP}$ and $\mathrm{AA}$, respectively, which is greater than in adult cows (75\%; Marini et al., 2008). The greater DM and forage intake and the lower nutrient concentration in the diet of adult cows may reduce digestibility of $\mathrm{N}$ in the small intestine due to a greater rate of passage and the larger presence of nonnitrogen components in the digesta, reducing the surface of contact between digesta and the absorptive tissue.

Table 3. Least squares means of apparent (ADD) and apparently true (ATDD) duodenal and ileal digestibilities (AID) of nutrients of 3-mo-old weaned calves

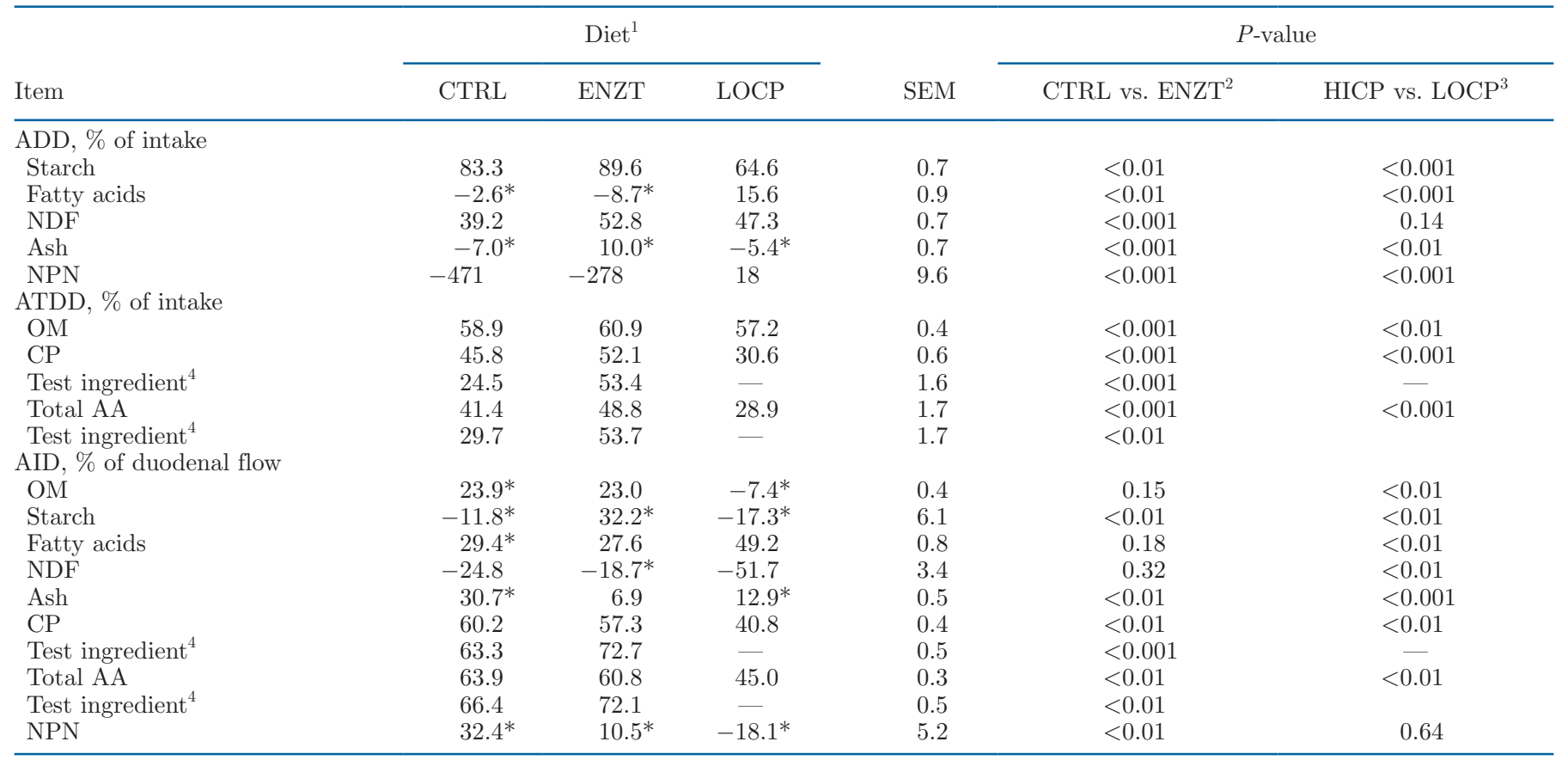

${ }^{1}$ Calves were fed ad libitum whether a control calf starter (CS) with conventional soybean meal as the main source of protein (CTRL), an isonitrogenous CS with an enzyme-treated soybean meal as the main source of protein (ENZT), and a CS with low content in CP (LOCP).

${ }^{2} P$-value of the orthogonal contrast between CTRL and ENZT diets $(\mathrm{n}=2)$.

${ }^{3} P$-value of the orthogonal contrast of CTRL and ENZT (HICP) against LOCP $(\mathrm{n}=2)$.

${ }^{4} \mathrm{ADD}$ and $\mathrm{AID}$ of the components (CP and total AA) of the test ingredient (conventional or enzyme-treated soybean meal in the CTRL and ENZT diet, respectively) as estimated by the difference method (Kong and Adeola, 2014).

$*$ Means were not different from zero with a $95 \%$ confidence interval. 
In conclusion, as long as the supply of dietary $\mathrm{CP}$ is sufficient, microbial protein contributes greatly to the flow of absorbed duodenal protein, and ruminal and abomasal digestion of starch and NDF is substantial in weaned calves at 3 mo of age. Endogenous protein losses are close to those in adult cows and account for more than half of the total $\mathrm{N}$ reaching the ileum. The use of an ESBM in CS increased its ruminal degradability, enhanced microbial efficiency and microbial $\mathrm{N}$ duodenal flow, and may be more digestible in the small intestine in comparison with conventional SBM. Nevertheless, these comparisons must be interpreted cautiously and further research is needed to verify these findings in a larger number of calves.

\section{ACKNOWLEDGMENTS}

Financial support was provided by Hamlet Protein A/S, Horsens, DK. The authors have not stated any conflicts of interest.

\section{REFERENCES}

Ansia, I., H. H. Stein, M. R. Murphy, and J. K. Drackley. 2019. Technical note: Establishment of an ileal cannulation technique in preweaning calves and use of a piecewise regression approach to evaluate effects on growth and $\mathrm{pH}$ fluctuation of ileal digesta. J. Dairy Sci. 102:11061-11066. https://doi.org/10.3168/jds.2019-16788.

Bach, A., S. Calsamiglia, and M. D. Stern. 2005. Nitrogen metabolism in the rumen. J. Dairy Sci. 88:E9-E21. https://doi.org/10.3168/ jds.S0022-0302(05)73133-7.

Chatterjee, C., S. Gleddie, and C.-W. Xiao. 2018. Soybean bioactive peptides and their functional properties. Nutrients 10:1211. https: //doi.org/10.3390/nu10091211.

Clark, J. H., T. H. Klusmeyer, and M. R. Cameron. 1992. Microbial protein synthesis and flows of nitrogen fractions to the duodenum of dairy cows. J. Dairy Sci. 75:2304-2323. https://doi.org/10 $.3168 /$ jds.S0022-0302(92)77992-2.

D'Mello, J. P. F. 2006. Chapter 14: Effects of antinutritional factors and mycotoxins on feed intake and on the morphology and function of the digestive system. Pages 419-438 in Biology of Growing Animals, volume 4. R. Mosenthin, J. Zentek, T. Żebrowska, ed. Elsevier, Amsterdam, the Netherlands.

Feng, J., X. Liu, Z. R. Xu, Y. P. Lu, and Y. Y. Liu. 2007. Effect of fermented soybean meal on intestinal morphology and digestive enzyme activities in weaned piglets. Dig. Dis. Sci. 52:1845-1850. https://doi.org/10.1007/s10620-006-9705-0.

Hoover, W. H., and S. R. Stokes. 1991. Balancing carbohydrates and proteins for optimum rumen microbial yield. J. Dairy Sci. 74:36303644. https://doi.org/10.3168/jds.S0022-0302(91)78553-6.

Huisman, J., and A. J. M. Jansman. 1991. Dietary effects and some analytical aspects of antinutritional factors in peas (Pisum sativum), common beans (Phaseolus vulgaris) and soybeans (Glycine $\max$ L.) in monogastric farm animals. A literature review. Nutr. Abstr. Rev. Ser. B 61:901-921.

Hvelplund, T., and M. Hesselholt.1987. Digestibility of individual amino acids in rumen microbial protein and undegraded dietary protein in the small intestine of sheep. Acta Agric. Scand. A Anim. Sci. 37:469-477. https://doi.org/10.1080/00015128709436578.

Ipharraguerre, I. R., Z. Shabi, J. H. Clark, and D. E. Freeman. 2002. Ruminal fermentation and nutrient digestion by dairy cows fed varying amounts of soyhulls as a replacement for corn grain. J. Dairy Sci. 85:2890-2904. https://doi.org/10.3168/jds.S0022 -0302(02)74377-4.
Khan, M. A., H. J. Lee, W. S. Lee, H. S. Kim, S. B. Kim, S. B. Park, K. S. Baek, J. K. Ha, and Y. J. Choi. 2008. Starch source evaluation in calf starter: II. Ruminal parameters, rumen development, nutrient digestibilities, and nitrogen utilization in holstein calves. J. Dairy Sci. 91:1140-1149. https://doi.org/10.3168/jds.2007-0337.

Khorasani, G. R., W. C. Sauer, L. Ozimek, and J. J. Kennelly. 1990. Digestion of soybean meal and canola meal protein and amino acids in the digestive tract of young ruminants. J. Anim. Sci. 68:3421-3428. https://doi.org/10.2527/1990.68103421x.

Kim, M. H., C. H. Yun, H. S. Kim, J. H. Kim, S. J. Kang, C. H. Lee, J. Y. Ko, and J. K. Ha. 2010. Effects of fermented soybean meal on growth performance, diarrheal incidence and immune-response of neonatal calves. Anim. Sci. J. 81:475-481. https://doi.org/10 $.1111 / \mathrm{j} .1740-0929.2010 .00760 . x$.

Kim, M. H., C. H. Yun, C. H. Lee, and J. K. Ha. 2012. The effects of fermented soybean meal on immunophysiological and stressrelated parameters in Holstein calves after weaning. J. Dairy Sci. 95:5203-5212. https://doi.org/10.3168/jds.2012-5317.

Klusmeyer, T. H., R. D. McCarthy Jr., J. H. Clark, and D. R. Nelson. 1990. Effects of source and amount of protein on ruminal fermentation and passage of nutrients to the small intestine of lactating cows. J. Dairy Sci. 73:3526-3537. https://doi.org/10.3168/jds .S0022-0302(90)79052-2.

Kong, C., and O. Adeola. 2014. Evaluation of amino acid and energy utilization in feedstuff for swine and poultry diets. Asian-Australas. J. Anim. Sci. 27:917-925. https://doi.org/10.5713/ajas.2014 .r.02.

Kwon, I. H., M. H. Kim, C. H. Yun, J. Y. Go, C. H. Lee, H. J. Lee, W. Phipek, and J. K. Ha. 2011. Effects of fermented soybean meal on immune response of weaned calves with experimentally induced lipopolysaccharide challenge. Asian-Australas. J. Anim. Sci. 24:957-964. https://doi.org/10.5713/ajas.2011.10419.

Lallès, J. P., and C. Poncet. 1990. Changes in ruminal and intestinal digestion during and after weaning in dairy calves fed concentrate diets containing pea or soya bean meal. 1. Digestion of organic matter and nitrogen. Livest. Prod. Sci. 24:129-142. https://doi .org/10.1016/0301-6226(90)90073-F.

Marini, J. C., D. G. Fox, and M. R. Murphy. 2008. Nitrogen transactions along the gastrointestinal tract of cattle: A meta-analytical approach. J. Anim. Sci. 86:660-679. https://doi.org/10.2527/jas .2007-0039.

Mariz, L. D. S., P. M. Amaral, S. C. Valadares Filho, S. A. Santos, E. Detmann, M. I. Marcondes, J. M. V. Pereira, J. M. Silva Júnior, L. F. Prados, and A. P. Faciola. 2018. Dietary protein reduction on microbial protein, amino acid digestibility, and body retention in beef cattle: 2. Amino acid intestinal absorption and their efficiency for whole-body deposition. J. Anim. Sci. 96:670-683. https://doi .org/10.1093/jas/sky018.

Meissner, H., and H. Du Preez. 2009. Ruminal and postruminal digestion of dietary protein and starch in steers: 1. Effect of protein concentration, degradation of protein and energy content of the diet. S. Afr. J. Anim. Sci. 26:59-65. https://doi.org/10.4314/sajas .v26i3.44319.

Montagne, L., R. Toullec, and J. P. Lallès. 2000. Quantitative and qualitative changes in endogenous nitrogen components along the small intestine of the calf. J. Sci. Food Agric. 80:2123-2134..

Montoya, C. A., S. J. Henare, S. M. Rutherfurd, and P. J. Moughan. 2016. Potential misinterpretation of the nutritional value of dietary fiber: Correcting fiber digestibility values for nondietary gut-interfering material. Nutr. Rev. 74:517-533. https://doi.org/ 10.1093/nutrit/nuw014.

Montoya, C. A., S. M. Rutherfurd, and P. J. Moughan. 2015. Nondietary gut materials interfere with the determination of dietary fiber digestibility in growing pigs when using the prosky method. J. Nutr. 145:1966-1972. https://doi.org/10.3945/jn.115.212639.

Olijhoek, D. W., A. L. F. Hellwing, M. Brask, M. R. Weisbjerg, O. Højberg, M. K. Larsen, J. Dijkstra, E. J. Erlandsen, and P. Lund. 2016. Effect of dietary nitrate level on enteric methane production, hydrogen emission, rumen fermentation, and nutrient digestibility in dairy cows. J. Dairy Sci. 99:6191-6205. https://doi.org/10 $.3168 /$ jds.2015-10691. 
Ouellet, D. R., M. Demers, G. Zuur, G. E. Lobley, J. R. Seoane, J. V. Nolan, and H. Lapierre. 2002. Effect of dietary fiber on endogenous nitrogen flows in lactating dairy cows. J. Dairy Sci. 85:3013-3025. https://doi.org/10.3168/jds.S0022-0302(02)74387-7.

Panah, F. M., S. Lashkari, A. L. Frydendahl Hellwing, M. Larsen, and M. R. Weisbjerg. 2020. Effects of toasting and decortication of oat on nutrient digestibility in the rumen and small intestine and on amino acid supply in dairy cows. J. Dairy Sci. https://doi.org/10 .3168/jds.2019-17142.

Prado, L. A., A. Ferlay, P. Nozière, and P. Schmidely. 2019. Predicting duodenal flows and absorption of fatty acids from dietary characteristics in ovine and bovine species: A meta-analysis approach. Animal 13:727-739. https://doi.org/10.1017/S1751731118001982.

Reynal, S. M., and G. A. Broderick. 2003. Effects of feeding dairy cows protein supplements of varying ruminal degradability. J. Dairy Sci. 86:835-843. https://doi.org/10.3168/jds.S0022-0302(03)73666-2.

Reynolds, C. K., and N. B. Kristensen. 2008. Nitrogen recycling through the gut and the nitrogen economy of ruminants: An asynchronous symbiosis. J. Anim. Sci. 86(Suppl 14):E293-E305. https: //doi.org / 10.2527/jas. 2007-0475.

Seo, J. K., M. H. Kim, J. Y. Yang, H. J. Kim, C. H. Lee, K. H. Kim, and J. K. Ha. 2013. Effects of synchronicity of carbohydrate and protein degradation on rumen fermentation characteristics and mi- crobial protein synthesis. Asian-Australas. J. Anim. Sci. 26:358 365. https://doi.org/10.5713/ajas.2012.12507.

Stein, H. H., B. Sève, M. F. Fuller, P. J. Moughan, and C. F. M. De Lange. 2007. Invited review: Amino acid bioavailability and digestibility in pig feed ingredients: Terminology and application. J. Anim. Sci. 85:172-180. https://doi.org/10.2527/jas.2005-742.

Valkeners, D., A. Théwis, F. Piron, and Y. Beckers. 2004. Effect of imbalance between energy and nitrogen supplies on microbial protein synthesis and nitrogen metabolism in growing double-muscled Belgian Blue bulls. J. Anim. Sci. 82:1818-1825. https://doi.org/10 2527/2004.8261818x.

van Bruchem, J., L. J. G. M. Bongers, S. C. W. Lammers-Wienhoven, G. A. Bangma, and P. W. M. van Adrichem. 1989. Apparent and true digestibility of protein and amino acids in the small intestine of sheep as related to the duodenal passage of protein and nonprotein dry matter. Livest. Prod. Sci. 23:317-327. https://doi.org/ 10.1016/0301-6226(89)90080-8.

\section{ORCIDS}

I. Ansia (ำ https://orcid.org/0000-0002-9114-4178

J. K. Drackley (ํ) https://orcid.org/0000-0002-4560-5594 